\title{
\begin{tabular}{ll} 
究 \\
\hline
\end{tabular} \\ 重心動摇の解析
}

一重心動摇パターンの定量化について一

山本昌彦

\section{Analysis of Body Sway of the Center of Gravity}

-A method for quantification of the pattern of stabilogram using the test of Wilks 1 -

\section{Masahiko Yamamoto}

(Toho University)

While few reports are available on the quantification of the pattern of the stabilogram, the objective classification of the pattern was attempted by Tokita in 1972, who recognized four patterns. We tried to quantify the pattern through a statistical approach in the present study.

Analysis was done using the method of Wilks $\Lambda$. This consists in dividing a sequence of changes in the location of the center of gravity into successive groups of change in a certain unit time and comparing the mean change in the location among different time groups.

As a result, the patterns of the stabilogram were quantitatively classified into three types, the fixed center, unfixed center and multiple center types. The $\Lambda$ value at 12 sec was $1.00-0.65$ in the fixed center type, $0.65-0.35$ in the unfixed center type, and $0.35-0.00$ in the multiple center type. We then drew a graph from the unit time and Wilks $\Lambda$ value, and named the curve thus obtained "Body sway pattern curve".

The multiple center type in the three patterns seems to have peculiar means that concern with the oculo-spinal reflex.

\section{はじめに}

質量のあるものには，重さの中心が在ると同様に，人間にも重心が存在する．乙の，人の重心を 知るためにその位置を始めて計測したのが 1680 年 Borelli である ${ }^{8)}$. その方法は, 平板の上に人を 寝かせ，平板の下に契状の支点を置きバランスの位置によって重心測定を行った．この測定で，一 次元的な方法ではあるが身体の重心位置を明らかにした。重心の位置を測定するに当たり，生体に おいては身体の摇れと共に重心位置が変化するため, 死体によって行なわれていた。 そてで, 重心 
の変化を逆に記録測定しようと考え，それを行ったのが 1929 年 Basler ${ }^{8)}$ であった。彼は，平板の 一端を可動性に固定し，あう一端を秤の上に置いた．この平板の上に人を立たせ，秤の針の变化を 記録した。乙れも一次元的ではあるが重心動摇の記録の始まりであった。現在行なわれているよう な，二次元的な動摇の記録を行ったのは1938年 Hellebrant ${ }^{9)}$ であった. 彼女は, 1900年 du Bols Reymond 重心位置測定用に考按した秤を，2台，直交させて使用し，前後，左右の同時記録を行 ったこの頃の動摇の検出装置は，ほとんどが機械的構造が主であり，現在の電気的な装置とは異 なり，非常な努力を要したととがうかがわれる．

現在, 私共の周囲には，エレクトロニクス器材が重要な位置を占め, 重心動摇の測定に関しても 従来と比較にならない精度と容易さを持っている. 特にコンピュータの導入は, 動摇の解析方法に 多くの道を開いた．先駆者が机上で時間をかけ研究したものや，為そうにも為し得なかった事など が，短時間の内に可能となり，重心動摇の定量解析の方向へと進んでいる.

しかし，現実には全ての解析方法が利用されているわけでななく，現在も重心動摇㲹録の基本之 なっているのが，一枚の動摇図である．私共は，乙の動摇図から何かお引き出そうと跳めているの む一つの現状である。

重心動摇を解析するには様々な方法と考えオがある。その中で，重心動摇図の二次元の面におい て得られる情報について考えた場合，大きく三つの要素に分けてみるてとが出来る．1つは動摇の 「形，又は型」であり，1つは「大きさ」，もう 1 つは動摇の「力向性」である．との三要素（動 摇図の三要素之表現したい）については，誰もが動摇の判定要素として経験的に判断して来た。

そこで私共は，動摇図を見た場合，考えさせられる「形」について定量的に判定するてとができ ないか,というととを目的に重心動摇パターンの定量化を試みた。

\section{研 究 方 法}

重心動摇の測定記録は, 重心動摇検出台, 検 出器として, 三栄測器製 1 G 02 型重心動摇計 を使用, 座標変換増幅器を通し, データレコー ダ磁気テープ，X-Yレコーダに記録した。增 幅器には, 補正回路を使用していない（図1).

データの解析は, データレコーダより, コン ピュータ P D P-12（D E C 社）に入力され,
演算を行った～A / D 変換時のサンプリング時

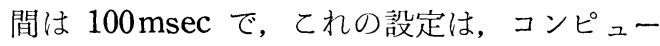
タメモリー容量や, 従来行われているコンピュ 一タ解析を参考にし，決定した。

測定に際し，記録条件は，足位を Romberg Position とし開眼・閉眼各 90 秒間測定. デー 夕解析時は, この内の安定した 60 秒間を使用し

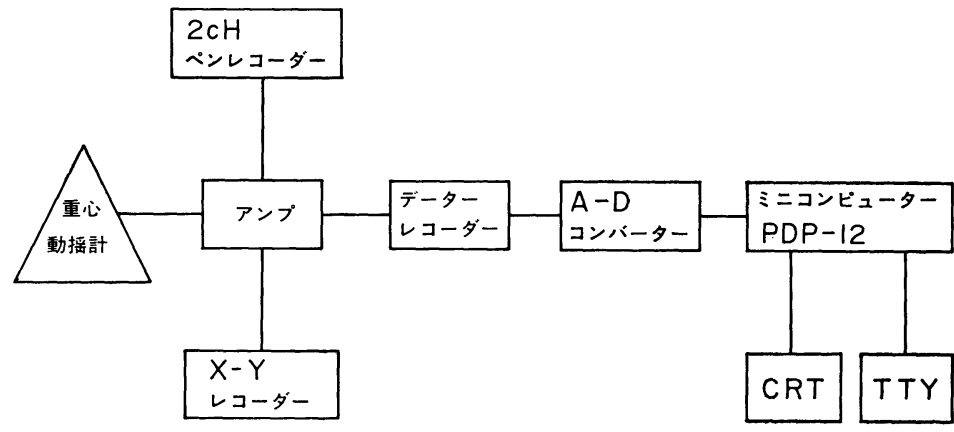

図 I重心動摇解析システム 
た. 開眼時の眼位は $3 \mathrm{~m}$ 前方の $\times$ 印の 1 点を注＼cjkstart視させた.

\section{重心動摇の解析について}

重心動摇を解析するに当って, 一番知りたい ことは, 言うに及ばず, 実際, どのような動摇 が起っているのかというととである。動摇図に ついても, どのような要素で動摇図が構成され ているかを知る必要がある.

先に述べたように, 動摇図は, 形, 大きさ, 方向の三つの要素より成っており, 時間の要素 は入っていない.つまり, 動摇図を表現するた めには, 最低この三つの要素を必要とするはず である.しかし，動摇図の特徵だけを表現する

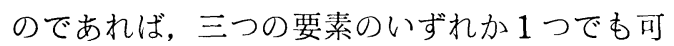
能である，三要素を端的に表現することは非常 に困難なととであるし，要素の1つを表現する にしてむ, その要素の中の, どの見方が適切か を決めるのも今後の問題と思われる. 現在「大 きさ」については, 距離, 面積等の方法が用い られ,大いに利用されている. 以下は, 要素の 1 つである形を定量化するための 1 方法である。
重心動摇データをコンピュータに入力する場 合, 前段で $\mathrm{A} / \mathrm{D}$ 変換を行う。こてで60秒間の 重心動摇データは，サンプリングされ， 0.1 秒 毎に切られた 600 個の点のデータとして記憶さ れる．との点をC R T に表示した時， 600 個の 点の集合として動摇図をみることができる. 動 摇図は線の集合であるが, コンピュータでは, 点の集合として扱われる. ての点の集合は，あ る点から始まり, ある点で終っているはずであ る. ある点から次の点に移る位置は, 時間や距 離, 方向により様々な広ろがりを示す。の広 ろがった各々の点の位置が互にどのような関係 になっているかを知るととによって, 点の構成 状態がわかる，つまり点のバラッキ具合の異っ た状態により形を定量的に分類できないか, と の意図で解析を行った。形定量の解析方法には 様々な方法があると思われる，今回私共は，統 計的な手法によりこの解析を試みた.

\section{解 析 方 法}

解析の方法としては，統計学的手法であるウ イルクスの $\Lambda$ (ラムダ) による検定によって行 った. ウイルクスのイによる検定とは, 一つの 集団と他の集団の平均の違いの状態を知るため に行う方法である.

実際には, 重心動摇記録データを $\mathrm{A} / \mathrm{D}$ 変換 し, サンプリングすることにより，6000点の
集合を作ることが出来る，乙の点の集合を，或 る時間で区切ることにより，いくつかの集団を 作ることができる. この集団の数は区切る時間 によって決定される.

例えば, 或る時間で区切り， 7 個の集団がで きたと仮定する，すると，図 2 亿示す如く 7 個 の集団の関係が次の三通り出来るとととなる.

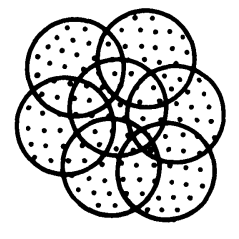

1

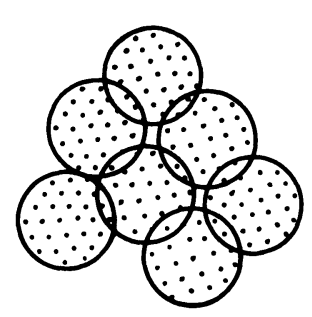

2

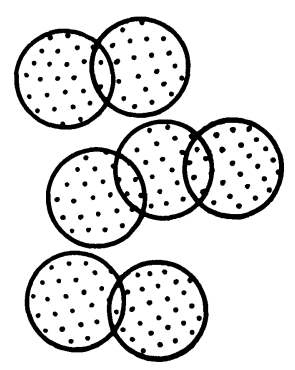

3

図 2 動摇図のサンプリングによる集団模図 
1) 互に大きく重なり合う．2）互が離れてい

る. 3 ）或るものは重なり合い, 重なったもの 以外は離れている，てのような関係を検定する ためには，先に述べたウイルクスのイによる検 定が適切と判断し，乙の解析方法を使うことと した.

ウイルクスのムについて式で表わすと, 以下 の如くである.

ウイルクスのイの考え方

例 : 1 元配置で考えると

$$
\mathrm{S}_{\mathrm{T}} \text { : 総平方和 }
$$

$\mathrm{S}_{\mathrm{w}}:$ 群内平方和

$\mathrm{S}_{\mathrm{B}}:$ 群間平方和

$\mathrm{x}_{\mathrm{i}}^{(\mathrm{k})}:$ グループ $\mathrm{k}$ における $\mathrm{i}$ 番目のデータ

$(\mathrm{i}=1,2 \cdots \cdots, \mathrm{nk})$

$\overline{\mathrm{x}}^{(\mathrm{k})}$ : グループ $\mathrm{k}$ の平均值 $(\mathrm{k}=1,2, \cdots$ $\cdots, \mathrm{m})$ $\overline{\overline{\mathrm{x}}}$ : 総平均

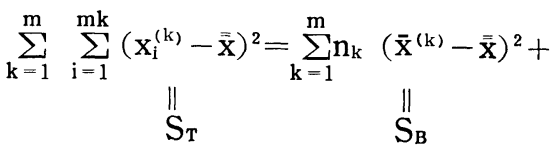

$$
\begin{aligned}
& \sum_{k=1}^{m} \sum_{i=1}^{n k}\left(x_{i}^{(k)}-\bar{x}^{(k)}\right)^{2} \\
& \stackrel{\|}{\mathrm{S}}
\end{aligned}
$$

総平方和 $\mathrm{S}_{\mathrm{T}}$ と群内平方和 $\mathrm{S}_{\mathrm{w}}$, 群間平方和 $\mathrm{S}_{\mathrm{B}}$ との関係は,

$$
\mathrm{S}_{\mathrm{T}}=\mathrm{S}_{\mathrm{W}}+\mathrm{S}_{\mathrm{B}} \text { である }
$$

この群間の変動の大きさの比率は

$$
\frac{\mathrm{S}_{\mathrm{B}}}{\mathrm{S}_{\mathrm{T}}}=1-\Lambda \quad \text { こてで } \Lambda=\frac{\mathrm{S}_{\mathrm{B}}}{\mathrm{S}_{\mathrm{T}}} \text { である }
$$

多変量の場合について拡張すると

$$
\Lambda_{\mathrm{n}}=\frac{\left|\mathrm{S}_{\mathrm{W}}\right|}{\left|\mathrm{S}_{\mathrm{T}}\right|} \text { であり, 統計学上では }
$$

ウイルクスの $\Lambda$ とよばれている

\section{解 析 成 績}

ウイルクスの $\Lambda$ にる検定を行なうためにデ 一タを時間で区切り，いくつかの集団を作らな ければならない. 今回は, 1 秒, 2 秒, 3 秒, 4 秒, 5 秒, 6 秒, 10 秒, 12 秒, 15 秒, 20 秒, 30 秒と11の時間で区切った。とれにより60秒間の 動摇データは, グループとして, 1 秒間で 60 集 団, 2 秒で 30 集団，3 秒で 20 集団というように， 表 1 に示したグループ数となる。 とのグループ 数の各々についてウイルクスの $\Lambda$ を求める.

表 2 は, このようにして演算された $\Lambda$ 值であ る（ウイルクスの $\Lambda$ による検定に求められた值 を $\Lambda$ 值と以下表わします). 開眼時と閉眼時に おける 1 被検者の $\Lambda$ である. $\Lambda$ 値は 1 に近い 程, グループ間の重なりが強いものと考えて良 い.
ここで, グループ数毎の $\Lambda$ 值の変化をわかり やすくするために，縦軸に $\Lambda$ 值，横軸にグルー プを作った時間を取り，グラフに表示すると表 2 に示した $\Lambda$ 值は図 3 に示すグラフとなる，同 時にこの動摇図を示した.

このような表示で, 同様の傾向を示したグラ フを持つ例を 3 例づつ動摇図と共に示す。図 4 , 図 5 , 図6（破線はグラフスケール上の最 大と最小の結線)。図 4 は曲線が破線より上に あり，上に凸のグラフを示し，動摇図は集中し ている．図 5 は，破線上か又は，やや下方に凹 のグラフで, 動摇図は大きく広万がっている. 図 6 は結線より大きく離れ，下に大きく凹なグ ラフとなっている．動摇図は明らかにいくつか の動摇中心を持っているように見える。こてに

表 I 60 秒間のデータを時間で区切った場合に出来る集団の数 (WILKS RAMUDR)

$\begin{array}{lcccccccccccc} & 1 & 2 & 3 & 4 & 5 & 6 & 7 & 8 & 9 & 10 & 11 \\ * * 2 \quad \text { 時間 (秒) } & 1 & 2 & 3 & 4 & 5 & 6 & 10 & 12 & 15 & 20 & 30 \\ \text { **集団の数 (グループ数) } & 60 & 30 & 20 & 15 & 12 & 10 & 6 & 5 & 4 & 3 & 2\end{array}$


(WILKS RAMUDR)

COMP NO $=52$

$\begin{array}{lccccccc}\text { **NO. } & 1 & 2 & 3 & 4 & 5 & 6 & 7 \\ \text { **SECONDS } & 1 & 2 & 3 & 4 & 5 & 6 & 10 \\ \text { **グループ数 } & 60 & 30 & 20 & 15 & 12 & 10 & 6 \\ (\text { NO.) } & & & & & & \\ (1) & 0.00929 & & & & 0.09798 \\ (2) & 0.05151 & & & & 0.31166 \\ (2) & 0.08391 & & & & 0.49391 \\ (3) & 0.15419 & & & & 0.51360 \\ (4) & 0.22301 & & & & 0.55191 \\ (5) & 0.21999 & & & & 0.63778 \\ (6) & 0.37618 & & & & 0.73666 \\ (7) & 0.64918 & & & & 0.74626 \\ (8) & 0.87560 & & & & 0.80880 \\ (9) & 0.73582 & & & & 0.78134 \\ (1) & 0.99753 & & & & 0.93987 \\ (10) & \text { 開 眼 } & & & & \text { 閉 眼 }\end{array}$

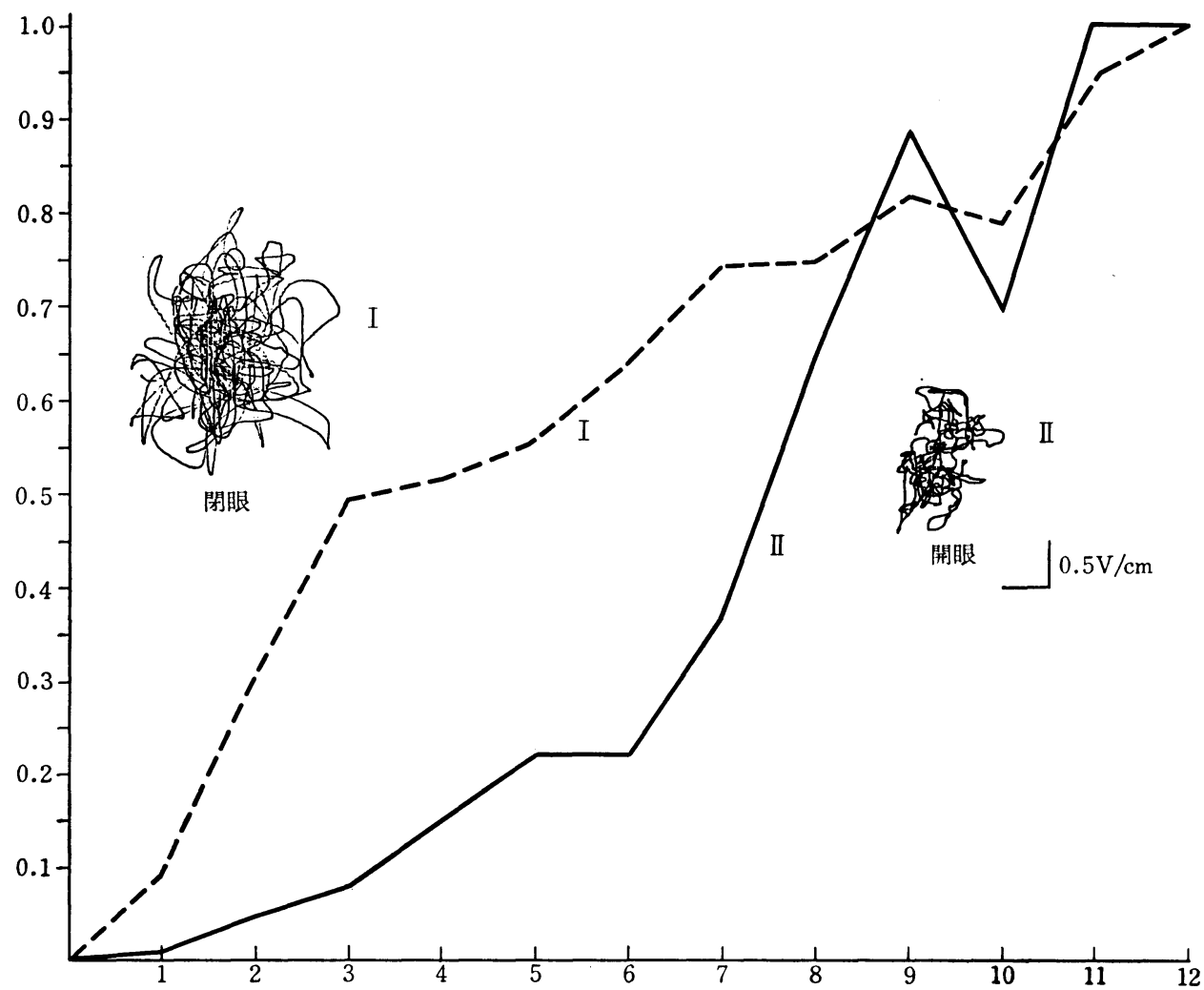

图 3 


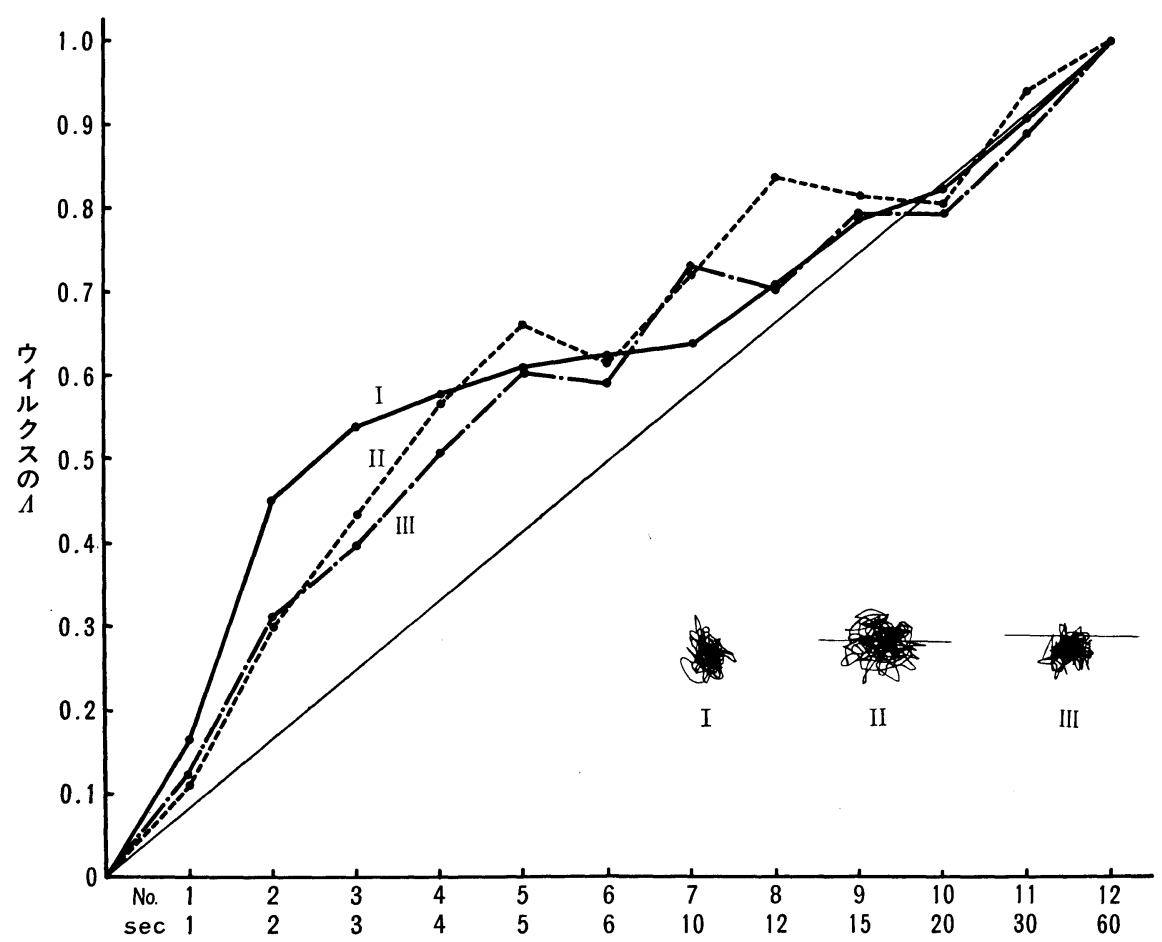

図 4

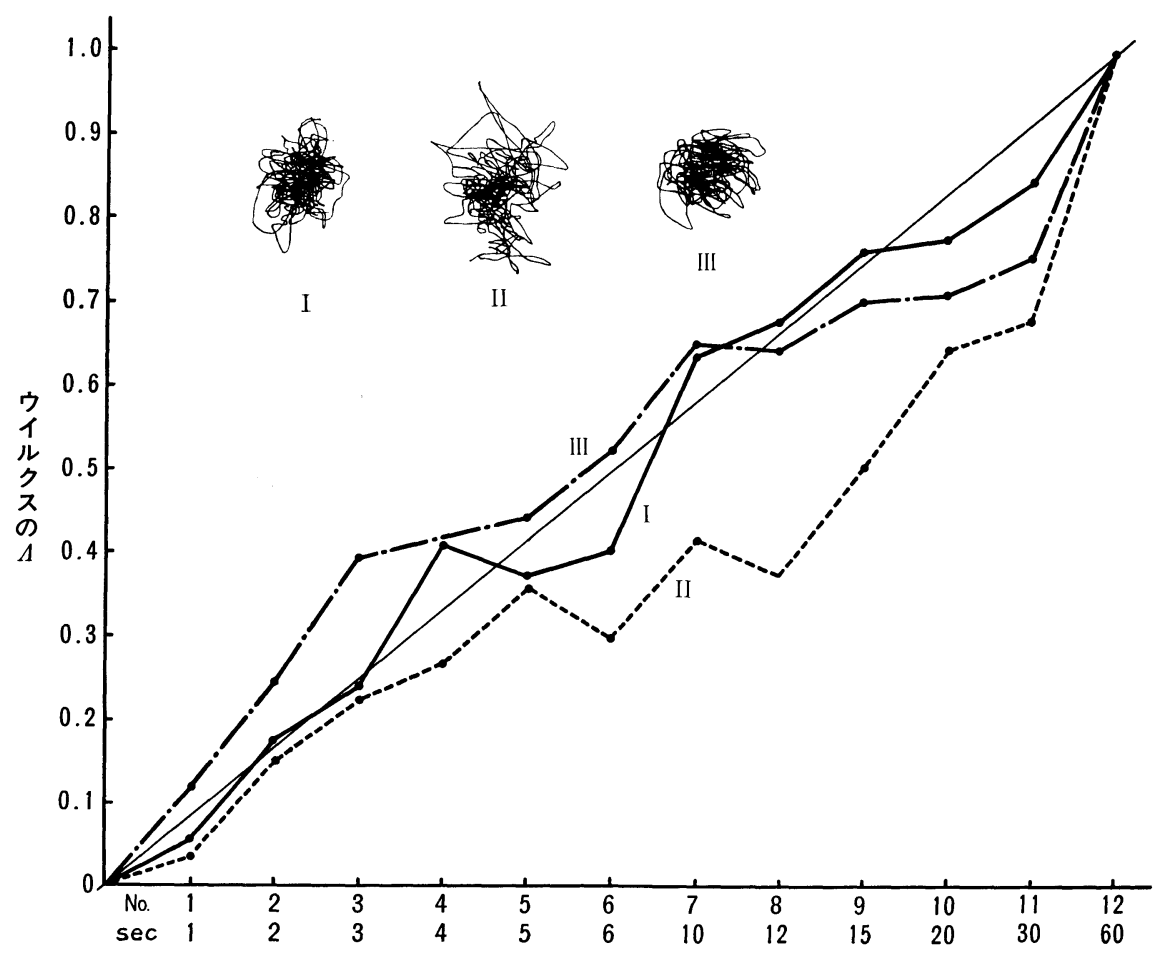

図 5 


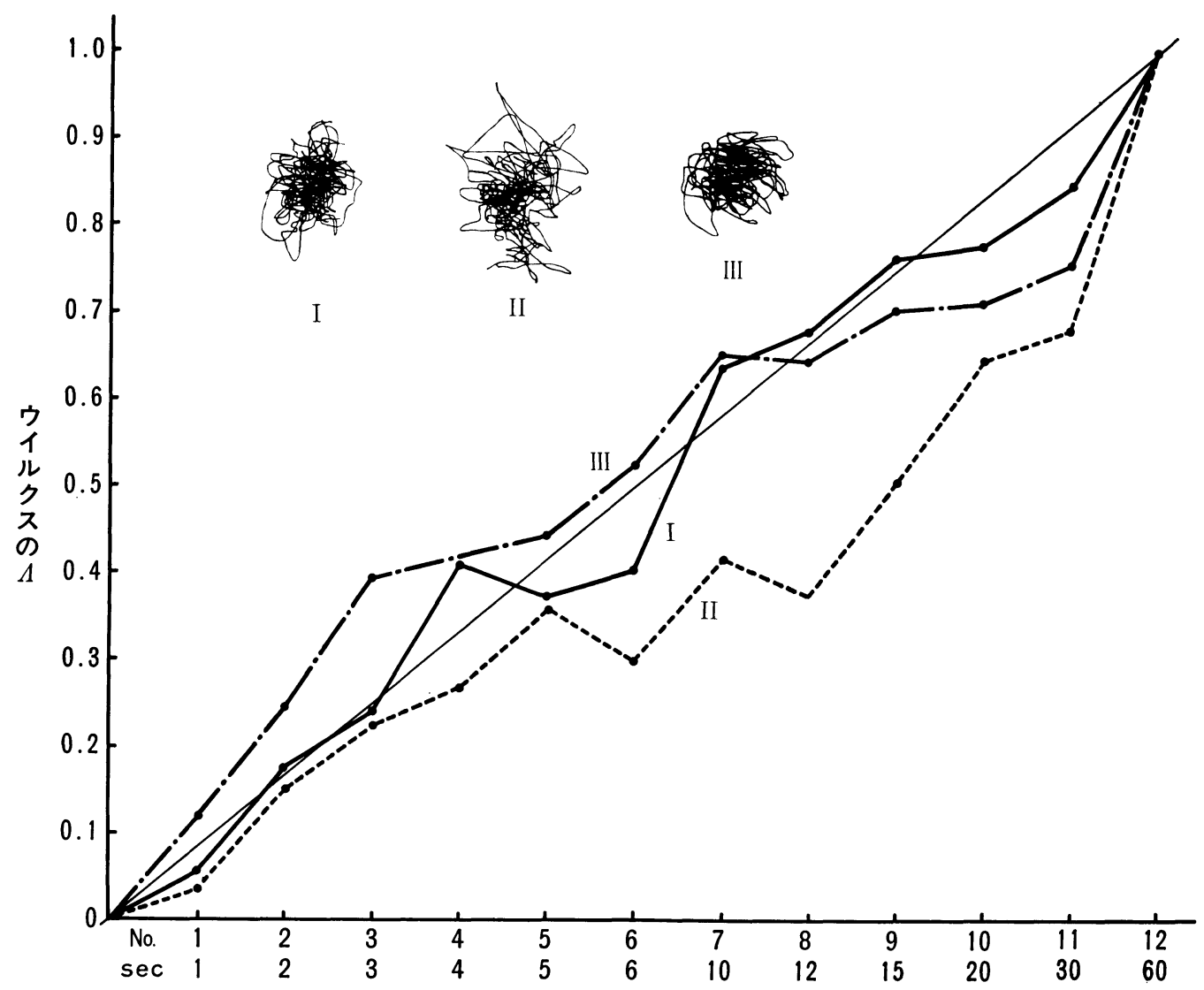

図 6

上げた 3 図の傾向を 1 枚のグラフ上に模式的に 描いたのが図 7 であり，動摇の違いによりグラ フが異って来ることがわかる.

しかし, 全ての動摇図とグラフがてのように はっきりと区別されるものではないむむしろ, 私共が主観的に動摇図を同じ傾向のものだけを 集め, グラフを描かせた所, 約半数は動摇図之 $\Lambda$ 值のグラフが一致しなかった。 その例を示し たのが図 8 である. 図 8 亿示した動摇図の傾向 からIは大きく広万がり，I， IIII集中してい るように判断するが, 先の図に示した曲線の分 類とは大きく異っている.

この違いは, 動摇図の主観的判断と, 定量化 による客観的判断の相異と考えて良いか否か, 迷う所であるが，今回は，それによる相異と考 えたい。

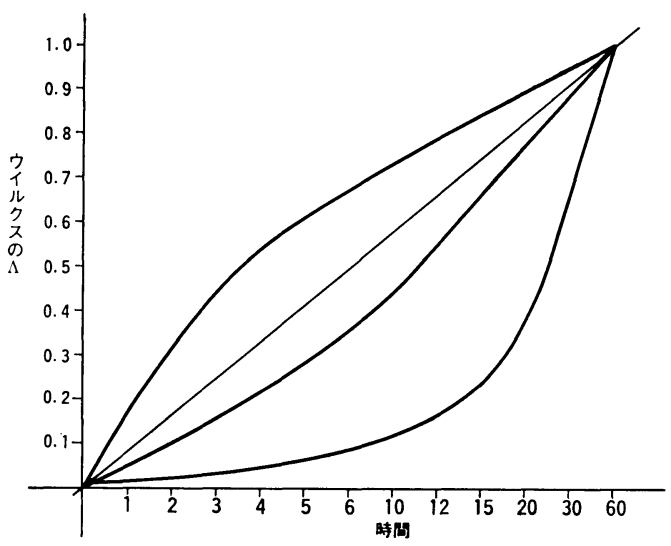

図 7 つの型の分類

以上のようにウイルクスの $\Lambda$ にるる検定によ って, 重心の移動変化を時間によって区切り, その関係の上に型を分類出来た，そこで型に名 


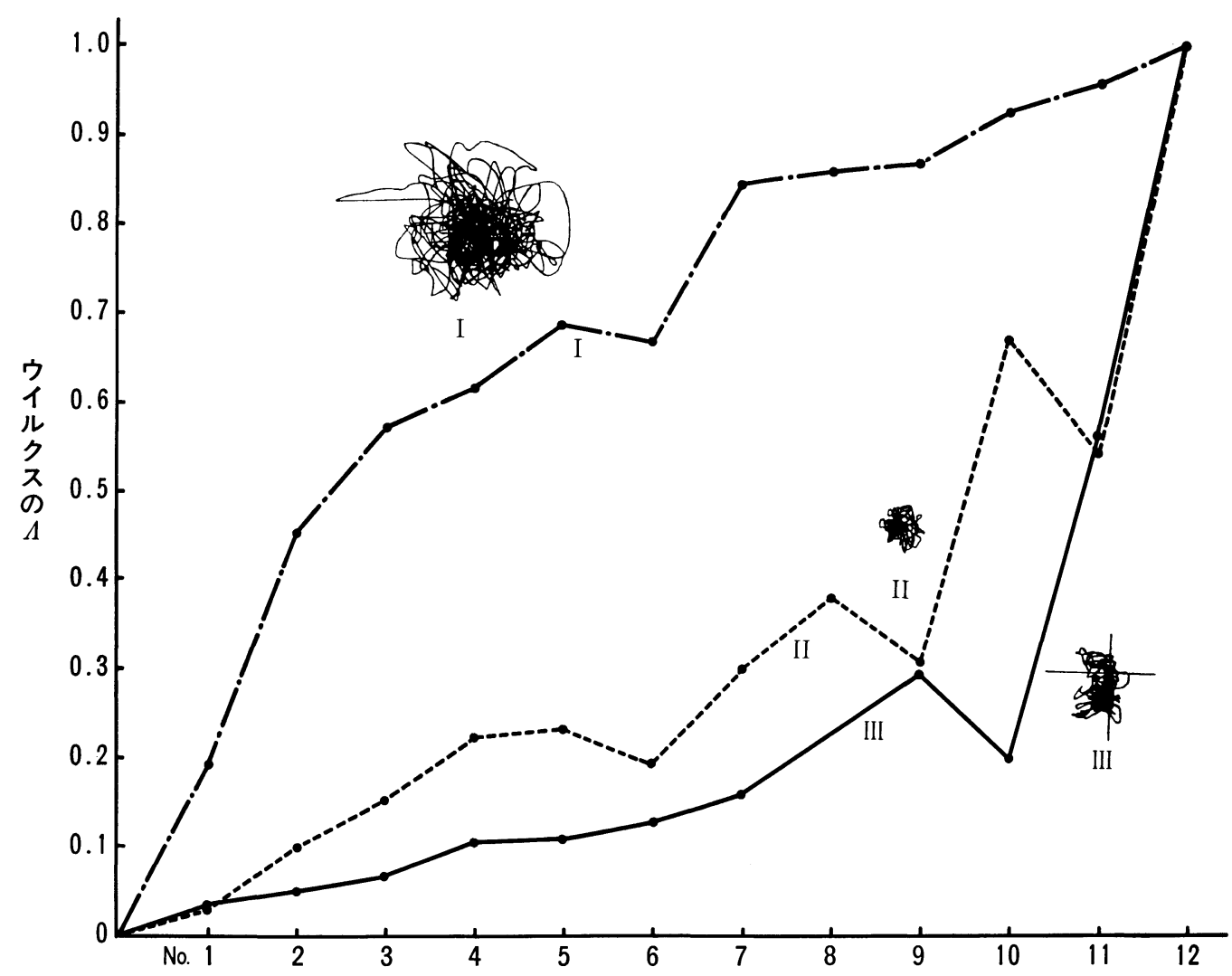

図 8 主観的な分類とに一致しない重心動摇図と $\Lambda$ 值曲線

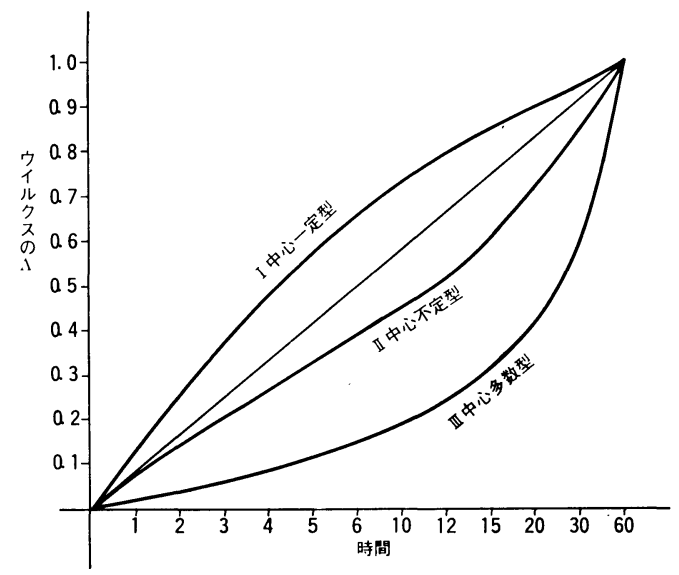

図 9 動摇形態曲線型分類

称を付けるべく, 図 4 に示したグラフ曲線を 「中心一定型」, 図 5 に示したグラフ曲線を「中 心不定型」図 6 に示したグラフ曲線を「中心多
数型」と 3 型に名称分類を行った. とのグラフ を私共は「動摇形態曲線」と呼ぶこととした (図9). 


\section{$\Lambda$ 値における型分類}

重心動摇図をウイルクスの $\Lambda$ による検定によ って 3 型に分類可能であるととがわかった。し かし, 動摇形態曲線では, 大体の型の分類はつ かめるが, 型を当てはめるためには， $\Lambda$ 值の数 的表示により型の分類区分を行なわなければな らない。図10に示したグラフは約 40 名の被検 者, 開眼時における $\Lambda$ 值をプロットしたもので ある，閉眼においても，ほぼ同様傾向のプロッ トが得られ， $\Lambda$ 值の広万がりにあまり大きな差 は認められない，てのような広ろがりを持つ $\Lambda$ 值で型の区分を設定するには，1つ1つ時間に よって出された $\Lambda$ 值で区分設定する必要は無 く，1 ケ所の $\Lambda$ 值で良い。そのため, 今回は,
$\Lambda$ 值の大きな広万がりを持つ時間の場所をむっ て区分設定するとととした，その時間は，図10

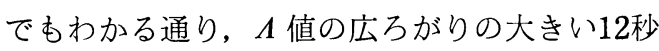
時に置いた。しかし，12秒時だけの $\Lambda$ 值では， $\Lambda$ 值に安定性を欠くため, 10 秒時と 15 秒時の $\Lambda$ 值を加え， 3 つの $\Lambda$ 值の平均を 12 秒時の $\Lambda$ 值之 仮定し，その值を示した。 しかし，型を分類す るための $\Lambda$ 值は，乙れを決定するための基準が 無いため, 今回は仮の值として決定した。この 決定は， 3 型がほぼ同数の $\Lambda$ 值を持たせるよう にし， $A$ 值の $0 \sim 0.1$ と0.9〜1.0の上限と下限の 数值が 12 秒時では非常に少ないので重要視せず $\Lambda$ 值 0.5 を中心にして考え，区分值を決めた.

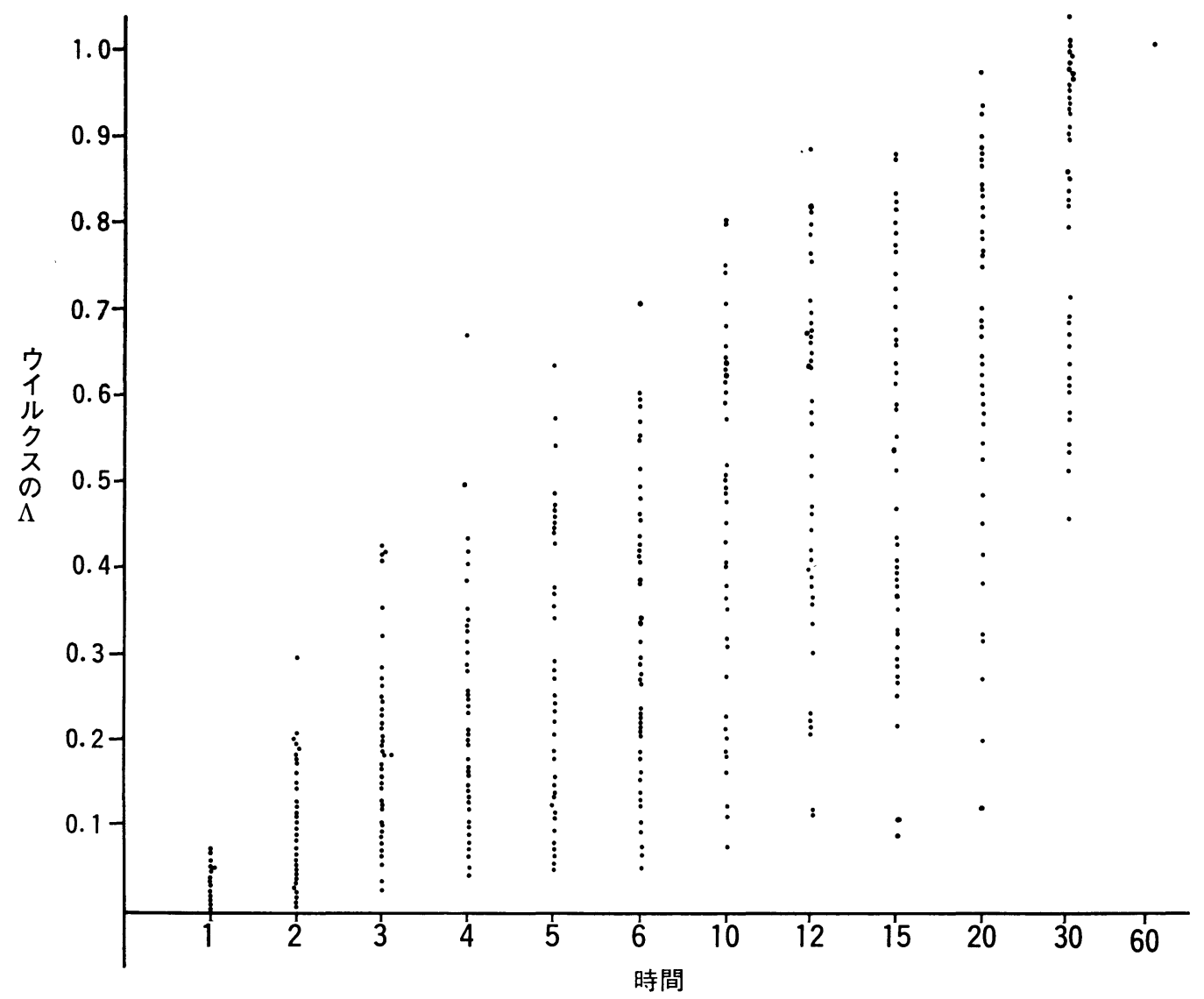

図 10 開眼 
表 3 動摇形態曲線（ウイルクスの $\Lambda$ ）による分類

\begin{tabular}{cc|c|c|c|c|c}
\hline 動 \\
分摇
\end{tabular}

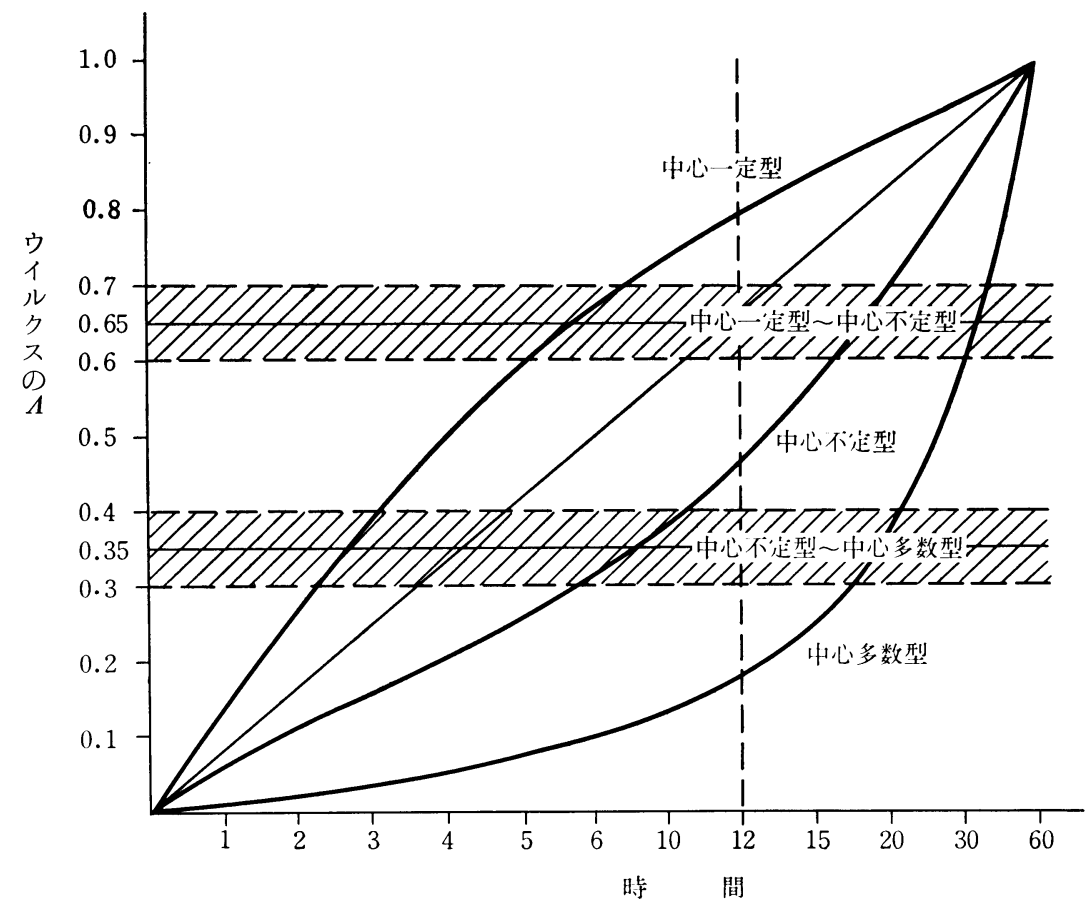

図II 動摇形態曲線と型分類

その結果，表 3 に示したように，分類法を 2 種類に分け，境界值を持たないものと，境界值 を持たせたものを，それぞれ分類法 I と分類法 Пとした. 分類型の名称と, 分類の $\Lambda$ 值はそれ ぞれ，分類法 I では，中心一定型1. 00〜 0. 65, 中心不定型 $0.65 \sim 0.35$, 中心多数型 $0.35 \sim$
0.00 とした. 分類法 IIでは, 境界值として, 士 0.05 の幅を持たせた。図11は，ての分類法の 区分を動摇形態曲線上に示したもので，区分值 は，12秒時のものである，分類法 I とПは，境 界值にある型が，I の分類よりどちらの傾向の 型であるかを知ることが出来る.

\section{正常者の重心動摇パターン}

ウイルクスの $\Lambda$ にる検定によって，分類法 に従い正常者の重心動摇パターン分類を行って みた，年令は 18才〜 59才，男性 18名，女性 16 名, 合計34名である.

分類は, 10 秒時, 12 秒時, 15 秒時の $\Lambda$ 值を加
え平均を取り，12秒時として $\Lambda$ 值を分類した. 表 4 は分類法 I, 分類法 Пによって分類した正 常者のあのである．乙の表によると，中心一定 型は, 開眼時よりあ閉眼時に多い傾向を認め る. 中心不定型は, 開眼時, 閉眼時共にあまり 
表 4 正常者重心動摇の型分類（ウィルクスの $\Lambda$ 值による）

$\mathrm{n}=34$

\begin{tabular}{|c|c|c|c|c|c|c|c|}
\hline & & 型 分 & 中心一定型 & $\sim$ & 中心不定型 & $\sim$ & 中心多数型 \\
\hline & & \multirow{2}{*}{$\Lambda$ 値 $(8 \Lambda)$} & $1.00 \sim 0.70$ & $0.70 \sim 0.60$ & $0.60 \sim 0.40$ & $0.40 \sim 0.30$ & $0.30 \sim 0.00$ \\
\hline & & & $1.00 \sim 0.65$ & & $0.65 \sim 0.35$ & & $0.35 \sim 0.00$ \\
\hline \multirow{2}{*}{ 分類法 } & \multirow{2}{*}{ II } & 開 & 7 & 3 & 9 & 4 & 11 \\
\hline & & 閉 & 9 & 9 & 8 & 5 & 3 \\
\hline \multirow{2}{*}{ 分類法 } & \multirow{2}{*}{ I } & 開 & 9 & I & 12 & / & 13 \\
\hline & & 閉 & 13 & I & 14 & l & 7 \\
\hline
\end{tabular}

表 5 重心動摇距離とパターン分類

（正常者 $\mathrm{n}=34$ )

\begin{tabular}{|c|c|c|c|c|c|c|c|c|c|}
\hline & \begin{tabular}{|c|} 
距 離 \\
$\mathrm{cm} / 60 \mathrm{sec}$
\end{tabular} & 型 & $\begin{array}{|cc|}\text { 距 } & \text { 離 } \\
\mathrm{cm} / 60 \mathrm{sec}\end{array}$ & 型 & & $\left|\begin{array}{cc}\text { 距 } & \text { 離 } \\
\mathrm{cm} / 60 \mathrm{sec}\end{array}\right|$ & 型 & \begin{tabular}{|c|c|}
$\begin{array}{c}\text { 距 } \\
\mathrm{cm} / 60 \mathrm{sec}\end{array}$ \\
\end{tabular} & 型 \\
\hline 1 & 36.00 & 不 定 & 54.69 & 一 定 & 18 & 53.75 & 不定>多数 & 94.42 & 一 定 \\
\hline 2 & 38.63 & 不 定 & 55.60 & 不 定 & 19 & 54.95 & 一 定 & 95.28 & 不 定 \\
\hline 3 & 40.24 & 一定 < 不定 & 65.35 & 一定>不定 & 20 & 55.27 & 多 数 & 98.27 & 不 定 \\
\hline 4 & 43.74 & 不定 $<$ 多数 & 71.53 & 多 数 & 21 & 55.85 & 多 数 & 99.09 & 一定>不定 \\
\hline $\begin{array}{l}4 \\
5\end{array}$ & 45.97 & 不 定 & 73.58 & 一 定 & 22 & 57.34 & 一 定 & 100.09 & 不 定 \\
\hline 6 & 46. 48 & 不 定 & 76.68 & 不 定 & 23 & 59.61 & 一 定 & 100.25 & 一 定 \\
\hline 7 & 48.63 & 一定>不定 & 80.40 & 一 定 & 24 & 61.33 & 多 数 & 100.37 & 不 定 \\
\hline 8 & 48.90 & 多 数 & 80.50 & 一定>不定 & 25 & 65.95 & 多 数 & 102.27 & 不定<多数 \\
\hline$y$ & 49. 36 & 不 定 & 82.39 & 一 定 & 26 & 66.06 & 多 数 & 102.42 & 不定 <多数 \\
\hline 10 & 50.90 & 一定>不定 & 83.42 & 一 定 & 27 & 66.43 & 多 数 & 104.39 & 一 定 \\
\hline 11 & 50.95 & 一 定 & 84.47 & 不 定 & 28 & 66.61 & 多 数 & 111.50 & 一定＜不定 \\
\hline 12 & 51.44 & 多 数 & 84.52 & 多 数 & 29 & 66.87 & 不 定 & 111.72 & 一定>不定 \\
\hline 13 & 51.89 & 不定>多数 & 85.52 & 不定<多数 & 30 & 70.07 & 一 定 & 121.50 & 一定＜不定 \\
\hline 14 & 52.14 & 一 定 & 86.92 & 一定＜不定 & 31 & 71.51 & 不 定 & 132.12 & 一定>不定 \\
\hline $\begin{array}{l}14 \\
15\end{array}$ & 52.20 & 一 定 & 91.42 & 多 数 & 32 & 75.40 & 不定>多数 & 144.52 & 一定 <不定 \\
\hline 16 & 53.01 & 不 定 & 93.82 & 一 定 & 33 & 84.34 & 多 数 & 146.03 & 不定>多数 \\
\hline \multirow[t]{2}{*}{17} & 53.59 & 多 数 & 94.13 & 一 定 & 34 & 90.58 & 不 定 & 186.17 & 一 定 \\
\hline & 開 & 眼 時 & 閉 & 時 & & 開 & 眼 時 & 閉 & 眼 時 \\
\hline
\end{tabular}

大きな差は認めない. 中心多数型は, 開眼時に おいて，他の型より多いが，閉眼時には極端に 少なくなっている.

このように正常者における型は，3 型と移行 型と色々な型が認められ，開眼時には 3 型ほぼ
均等にあり,どの型あある。しかし，乙の 3 型 の中で, 中心多数型が, 他の型に比較し, 開眼 時と閉眼時に大きな差を認め, との型は，視覚 系と姿勢の調節に関係を深く持つもののように 考えられる.

\section{重心動摇距離（動摇の大きさ）とパターンの関係の在り方}

34名の正常者について型分類を行った場合, 3 型全てがあり, 特に開眼時ではどの型になっ ても不思議は無い.しかし, 動摇の型はそれぞ
れに「大きさ」を持っている，そてで，「大き さ」と「型」にどのような傾向を持っているか を先の34名の正常者について比較した. 
表 5 は,「大きさ」として重心動摇移動距 離7) を使い, 距離の短かい例より順に並べたも のである．この表より型の傾向をみた場合，開 眼時では, 距離の短かいものに中心不定型が多 く, 中程に中心一定型，距離が長くなるものに 中心多数型が増える傾向を示している. 閉眼に なると, 主に中心一定型と中心不定型で, 大き な傾りが無く，混在している.

このような傾向から，正常者に打ける重心動 摇の在り方を推測することが出来る。つまり， 開眼時における重心動摇が，姿勢一眼反射の上 に強く成り立っていると考えた場合,

1 ）開眼時における重心動摇の小さいものはこ の動摇全体からみた重心の移動中心が明確に とらえられず, 動摇の中心を外れ動摇してい ると思われる。そのため, 動摇の小さいもの
に中心不定型となり易い傾向を持つ.

2 ）動摇の広万がりが大きくなるにつれ，全体 の動きは見かけ上，移動中心を持ったように 中心へと移動をくり返す。このため，ある程 度以上の大きさを持つと, 中心一定型になり 易い。

3 ）閉眼においては, 姿勢一眼反射が無くなる ために，重心動摇に型の上での規則性は消失 し，動摇の大きさに関係無く，種々の型を示 すむのと思われる。

4 ）中心多数型は, 中心一定型のいくつかの集 まりと考えられ，動摇中心がある時間内に何 度か変わるものである．姿勢制御に非常に細 かく反応しながら中心固定するため全体の移 動距離は大きくなると思われる.

\section{中心多数型と姿勢眼反射}

中心多数型は表 4 にも示したように，開眼時 には非常に多いにもかかわらず，閉眼時には極 端に少なくなってしまう。乙の率は，姿勢一眼 反射に密接な連りを持つ独特の型と思われる. この型は，ある時間を区切って移動中心を抁え 位置決めをし，そてで中心一定型のような動摇
をする，乙の位置決めをすることが，単に中心 一定に動摇するととと別に，姿勢制御の在り方 とみることができる.

そこで, 中心多数型が平衡障害と, どのよう な傾向にあるか, 若干の症例の型分類を行って みた。表 6 は, 平衡機能異常者15名の開眼時,

表 6 異常者症例とパターン

\begin{tabular}{|c|c|c|c|c|c|}
\hline 症 例 & 年 令 & 性 別 & 患 & 開眼 時 & 閉 眼 時 \\
\hline 1 & 56 & 우 & 両側 $x=エ ー ル ~\left(r_{\mathrm{s}}>1_{\mathrm{s}}\right)$ & 一定～不定 & 一 定 \\
\hline 2 & 57 & 우 & 多発性硬化症 & 不 定 & 不 定 \\
\hline 3 & 55 & $\hat{o}$ & 左前庭神経炎 & 一定～不定 & 一 定 \\
\hline 4 & 51 & 우 & 小脳出血 & 一 定 & 一 定 \\
\hline 5 & 42 & 우 & 脊髄小脳変性症 & 不 定 & 一 定 \\
\hline 6 & 63 & $\hat{\delta}$ & 小脳出 血 & 一定～不定 & 一定～不定 \\
\hline 7 & 53 & $\hat{o}$ & 右聴神経腫痬 & 不定〜多数 & 不 定 \\
\hline 8 & 37 & $\hat{o}$ & 小脳腫煌 & 不定～多数 & 不 定 \\
\hline 9 & 63 & 우 & 右小脳橋角腫場 & 不 定 & 一 定 \\
\hline 10 & 47 & $\hat{o}$ & 両側前庭機能低下 & 多 数 & 一 定 \\
\hline 11 & 56 & $\hat{o}$ & 左前庭機能低下 & 多 数 & 一 定 \\
\hline 12 & 27 & $\hat{o}$ & 右聴神経腫煌 & 不 定 & 不 定 \\
\hline 13 & 37 & 우 & 右聴神経腫煬（術後） & 一 定 & 不 定 \\
\hline 14 & 43 & 우 & 左前庭神経炎 & 一 定 & 一 定 \\
\hline 15 & 46 & $\hat{\delta}$ & 右前庭機能低下 & 多 数 & 不 定 \\
\hline
\end{tabular}


閉眼時について重心動摇型分類したあのであ る. まず閉眼時においては，中心多数型は一例 屯無く，中心一定型又は中心不定型又はその移 行型である. 開眼時において, 中心多数型の認 められるのは，ほとんど末稍前庭疾患の症例で あり，かつ注視眼振の消失しているあのだけで

考

重心動摇の「型」の分類は，現在までほとん ど行なわれていない．1972年，時田6)により分 類されただけである. この分類は，図12に示し たように，前後型・求心型・びまん型・多中心 型の 4 型に分類している．時田による動摇型分 類は, 動摇図の判定に 1 つの方向を示し, 重心 動摇を容易に表現，分類することを可能にし た。この判定方法は明快でありかつ有用であ る。しかし, 型の判定が, 主観によるという難 点をもっていることがある.

動摇型分類が定量的に判定出来るならば，一

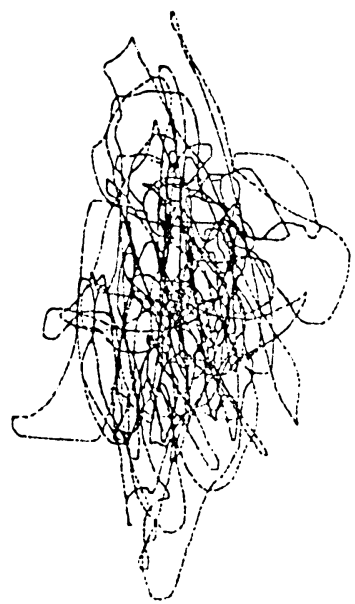

1

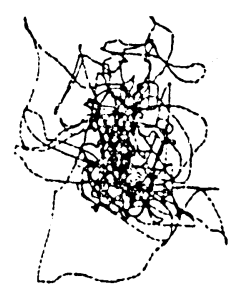

2

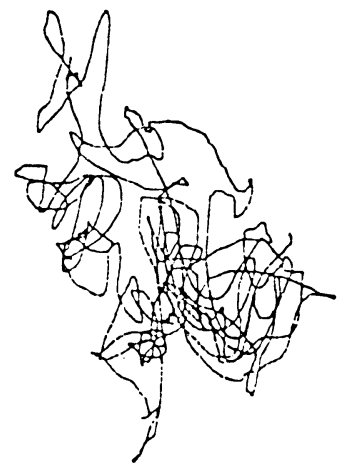

3

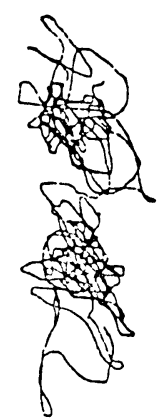

4

1. 前後型

2 . 求心型

3・びまん型

4. 多中心型

(1) 前後型：前後への動摇成分を主とするもの

（2）求心型：ある一点を中心に, 偏倚・立直りをくり返すもの

（3）びまん型：中心を持たず，全体的に動摇するもの

（4）多中心型：2 個以上の中心を作り動摇するもの

耳鼻臨床 $65 ： 5$

図12 時田らによる身体動摇型の分類 
開眼時と閉眼時では，型の在り方の考えを変え てみなければならず，当然，正常者之異常者の 型も異なった角度より考えなりればならない。
型の分類 1 つにしてあ非常に多くの問題を持っ ている，今後，症例を重㱛，臨床的な型につい て検討し，発展に尽したい。

\section{ま と め}

1 ）重心動摇パターンを定量化するす法の1つとして, 統計的手法であるウイルクスのイによる 検定によって定量可能であることがわかった。

2 ）重心動摇パターンを定量的に表現するために，経時的に区分した時間と，ウイルクスの $\Lambda$ 值 をむってグラフ化し，乙れを動摇形態曲線と名付けた。

3 ）動摇形態曲線によるパターン名称は,「中心一定型」「中心不定型」「中心多数型」に, 経 時的な移動中心の在り方により三型に分類した。

4 ）重心動摇パターンの分類する $\Lambda$ 值を, 10 秒時, 12 秒時, 15 秒時の $\Lambda$ 值の総和平均とし, それ を12秒時として表示した．分類は，分類法 I ，分類法Пの 2 通りで行った.

5 ）中心一定型, 中心不定型はどのような状態でも起こるが，正常者開眼では動摇の小さいもの の方に中心不定型が多い.

6 ）中心多数型は姿勢一眼反射に深い関係をもった型である.

稿を終るに当り，御高閲を賜った小松崎篤教授に深謝いたします．また，本研究に御協力いただいた慶大工学 部竹内寿一郎先生に心より謝意を表します。

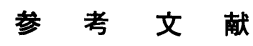

1）島薗順次郎：種々ノ突患二於ケル身体動摇二就 テ. 東医誌 $22: 24 ； 1022 \sim 1044,1908$.

2 ）大原義司：直立時二於ケル身体動摇二就テ。福岡 医誌 $18 ： 379 \sim 384,1925$.

3 ）猪飼達夫：直立姿勢の研究一直立時動摇曲線の分 析一. 日本生理学雑誌 $9: 198 \sim 222,1944$.

4) 執行英毅：姿勢の安定性に関する力学的研究. 耳 鼻臨床 $51 ： 907 \sim 950,1958$.

5）森貞近見：ヒトの起立保持機構の解析 I 〜 III. 長 大神経情報研年報（1975，1950） $2 ： 108 \sim 122$, $123 \sim 129$.

6) 時田 喬：頭部並びに重心動摇計による立直り反 射検查. 耳鼻臨床 $65 ： 5 ； 443 \sim 456,1972$.

7) 田口喜一郎：重心動摇軌跡距離測定法. 日耳鼻 $79: 835 \sim 843,1976$.

8 ) Basler, A. : Zur Rhysiologie des Hockeno. Z. Biol., $88:$ 523 530, 1929.

9 ) Hellebrandt, F.A. et al : The location of the cardinal and terminal orientation planes passing through the center of weight in young adult woman. Am. J. Physiol., $121: 465 \sim 470$, 1938.

10) Robert H. Wilkins : Romberg's sign Arch Neurol Vol. 19, 123 126, 1968.

11) T.S. Kapteyn: After though about the physico and Mechanico of the Postural Sway Agressologie Vol. 14C, 27〜35, 1973.

12) G. J. Snijders \& M. Verduin : Stabilograph, an accurate instrument for sciences Inderested in postural eguilibrium Agressologie $14 \mathrm{C}$, 15 20, 1973.

原稿到着 : 昭和 57 年 7 月 19 日
別刷請求先: 山本昌彦
厂143 東京都大田区大森西 5 丁目
東邦大学医学部耳鼻咽喉科学教室

